\title{
Evaluation day activity of patients with bronchial asthma in dependence on the clinical variant of the disease
}

Key words: bronchial asthma, Epworth's scale, drowsiness.

The syndrome of obstructive sleep apnea (SOAS) is characterized by episodes of cessation or limitation of air flow during sleep on the background of the sustained effort of respiratory muscles. The decline of the respiratory tract by inhalation leads to a decrease in the oxygen content in the blood, tissue hypoxia and organs. Episodes of apnea and hypopnea end with awakening with the restoration of biochemical parameters. Then the process is repeated again [1]. The prevalence of SOAS in the population varies from 0.4 to $9.1 \%$ in men and $4.0-4.4 \%$ in women [2]. Episodes of apnea during sleep lead to hypoxia, which, due to activation of the chemoreceptors of the carotid arteries, causes an increase in pulmonary ventilation hyperventilation. It can be assumed that the presence of sleep disturbances (breathing stops with desaturation) in SOAS can provoke or exacerbate changes in the pattern of breathing during the day, acting as a trigger factor that triggers the development of LDCs. Neurorespiratory syndrome (LDL) is characterized by a number of somatic symptoms caused by the formation of a stable pathological respiratory pattern, which is manifested by an increase in pulmonary ventilation inadequate to the level of gas exchange in the body [4]. According to various authors, the prevalence of this pathology is from 6 to $28 \%$ among patients with a general profile in the distribution of men and women 1: 4-1: 5 [5]. Patients with bronchial asthma (BA) and SOAS have well-studied hypoventilation breathing problems at night, but there is virtually no evidence of hyperventilation. However, general factors such as psycho-emotional stress, sleep deprivation, hypertension, autonomic nervous system imbalance, endothelial dysfunction, and oxidative stress are characteristic of both SOAS and LDCs [6].

Sleep disturbance is one of the frequent symptoms in patients with BA with uncontrolled course.

(c) O.A. Kanarskyi, 2018

www.search.crossref.org

DOI: 10.31655/2307-3373-2018-4-12-18
At a more detailed survey in many patients, subjective sleep deprivation, daytime drowsiness, short sleep in monotonous work, increased daytime fatigability, morning headaches, morning sickness, dry mouth after awakening, changes in potency, or other sexual disorders can be detected. Deepening of the degree of obstruction, the ability to deepen breathing, as well as the increase in respiratory volume and pulmonary ventilation in patients with BA in response to physical activity are reduced. They are characterized by a significant increase in respiratory rate, which is supported by a corresponding load of a minute volume of breathing (COD) [3]. Changes in the parameters of external respiration contribute to increasing the time adaptation of patients to exercise and a significant increase in energy costs. According to the same authors, a rather close correlation between the indicators of central hemodynamics and the function of external respiration was not revealed, indicating a violation of the coordinated activity of the cardiovascular and respiratory systems, and the presence of various variants of hemodynamics with unidirectional changes in respiration function in patients during and outside an attack [4]. Therefore, the main objective of the work was to assess the daily lifestyle of patients with BA, depending on the control of the course of the disease.

\section{Materials and methods}

The study was conducted on the basis of the State Enterprise «State Institution» National Institute of Phthisiology and Pulmonology named after F.G. Yanovsky of National Academy of Medical Sciences of Ukraine». As a result of this work, 40 patients with asthma (residents of Kyiv and Kyiv region) were screened consistently in the phase of exacerbation and remission, from 28 to 68 years old (middle age $(41.2 \pm 6.0)$ years), 
including 17 men and 23 women $[9,10]$. The work is done at public expense.

When the diagnosis of BA was taken into account of the history, clinical symptoms, indicators of the function

Table 1. Results of the questionnaire of the patients under study $(\mathrm{M} \pm \mathrm{m})$

\begin{tabular}{|c|c|c|}
\hline Indexes & $\begin{array}{c}\text { Number } \\
\text { of patients, } \\
n\end{array}$ & $\begin{array}{c}\% \\
\text { patients } \\
(n=60)\end{array}$ \\
\hline 1 & 2 & 3 \\
\hline \multicolumn{3}{|l|}{$\begin{array}{l}\text { The first symptoms of the } \\
\text { disease: }\end{array}$} \\
\hline - cough & 12 & $30,0 \pm 7,2$ \\
\hline $\begin{array}{l}\text { - shortness of breath with } \\
\text { physical activity }\end{array}$ & 15 & $37,5 \pm 7,7$ \\
\hline - episodes of wheezing & 5 & $12,5 \pm 5,2$ \\
\hline - attacks of difficult breathing & 25 & $62,5 \pm 7,7$ \\
\hline $\begin{array}{l}\text { Seasonality of manifestations } \\
\text { of symptoms }\end{array}$ & 28 & $70,0 \pm 7,2$ \\
\hline $\begin{array}{l}\text { Connection of the symptoms } \\
\text { of the disease with allergens }\end{array}$ & 9 & $22,5 \pm 6,6$ \\
\hline $\begin{array}{l}\text { The connection of the symptoms } \\
\text { of the disease with respiratory } \\
\text { infections }\end{array}$ & 25 & $62,5 \pm 7,5$ \\
\hline $\begin{array}{l}\text { Connection of symptoms } \\
\text { of a disease with physical activity }\end{array}$ & 15 & $37,5 \pm 7,7$ \\
\hline \multicolumn{3}{|c|}{ Frequency of exacerbations, once a year: } \\
\hline 0 & 8 & $20,0 \pm 6,3$ \\
\hline $1-2$ & 30 & $75,0 \pm 6,2$ \\
\hline $3-4$ & 2 & $5,0 \pm 3,4$ \\
\hline$>4$ & 0 & $0 \pm 0,0$ \\
\hline \multicolumn{3}{|l|}{ Severity of exacerbations: } \\
\hline light & 20 & $50,0 \pm 7,9$ \\
\hline moderate & 20 & $50,0 \pm 7,9$ \\
\hline severe & 0 & $0 \pm 0,0$ \\
\hline \multicolumn{3}{|l|}{ Hospital frequency, once a year: } \\
\hline 0 & 28 & $70,0 \pm 7,2$ \\
\hline $1-2$ & 10 & $25,0 \pm 6,8$ \\
\hline $3-4$ & 2 & $5,0 \pm 3,4$ \\
\hline$>4$ & 0 & $0 \pm 0,0$ \\
\hline
\end{tabular}

Average duration of exacerbation, days:

\begin{tabular}{|l|c|c|}
\hline up to 14 days & 20 & $50,0 \pm 7,9$ \\
\hline $14-21$ & 20 & $50,0 \pm 7,9$ \\
\hline $21-30$ & 0 & $0 \pm 0,0$ \\
\hline$>30$ & 0 & $0 \pm 0,0$ \\
\hline
\end{tabular}

of external respiration, reversibility of obstruction in the sample with bronchodilator. The selection of patients in the severity of BA was conducted in accordance with the criteria of Order No. 128 of the Ministry of Health of Ukraine of 19.03.2007 «On Approval of Clinical Protocols for the Provision of Medical Aid in the field of Pulmonology». In all patients, the diagnosis of BA was correctly established, confirmed both clinically and functionally (by means of spirometry and bronchial obstruction reversal test with short-acting $\beta_{2}$-agonist; SABA) [8].

The longitude of the disease in patients of the I group was $(4.3 \pm 2.8)$ years, the frequency of exacerbations of BA $(0.8 \pm 2.3)$ times / year. In patients of the II group $(9,4 \pm 2,8)$, the frequency of exacerbations of BA $-(1,8 \pm$ 2,3 ) times / year. More detailed information is presented in Table 1.

Of the 40 examined patients, 10 had signs of lung persistent flow, $30-$ moderate severity. In the majority of patients, the first symptoms of the disease were attacks of difficult breathing and respiratory episodes in 25 (62.5 \pm $7.7) \%$ and $5(12.5 \pm 5.2) \%$ of patients respectively. From coughing episodes the disease began in 12 patients $(30.0 \pm$ 7.2)\%. The seasonal symptoms of the disease were observed in 28 respondents $(70,0 \pm 7,2)$, the association of symptoms with allergens at $9(22,5 \pm 6,6) \%$. The connection of the symptoms of the disease with respiratory infections was in 25 patients $(62.5 \pm 7.5) \%$, the association of symptoms with physical activity in 15 patients $(37.5 \pm 7.7) \%$.

Frequency of exacerbations per year: there were 8 patients $(20,0 \pm 6,3) \%, 1-2$ times a year - in 30 patients $(75,0 \pm 6,2 \%), 3-4$ times - in 2 patients $(5,0 \pm 3,4) \%$. In 20 patients, the severity of exacerbation was mild (50.0 \pm $7.9) \%$, in the remaining $20-$ moderate severity (50.0 \pm 7.9)\%.

28 patients per year did not have any episode of hospitalization $(70,0 \pm 7,2) \%, 1$ to 2 times -10 patients $(25,0 \pm 6,8) \%$, in 2 patients $-3-4$ times $(5,0 \pm 3.4) \%$. The average duration of exacerbation up to 14 days was 20 in the examined $(50,0 \pm 7,9) \%$, in the remaining 20 from 14 to 21 days $(50,0 \pm 7,9) \%$.

Patients of both groups were examined according to general-clinical parameters and analyzed in the phase of exacerbation of the disease and in the remission period. To compare the obtained data, 10 patients from group I and 10 patients from the II group in random order were selected. The following results are obtained.

In the phase of exacerbation of BA, $60 \%$ of patients in the I group and $80 \%$ of patients in the II group complained of periodic pains in the heart, a feeling of «heartbeat». In the group of healthy, periodic pain in the heart region complained about $20 \%$ of those polled. Changes in the electrocardiogram were not detected in any of the subjects from the I group and in the healthy group, out of 10 patients in the II group, 2 had signs of coronary heart disease, 1 - signs of left ventricular hypertrophy, $1-$ sinus arrhythmia. $60 \%$ of the respondents in the I group and $70 \%$ of the II group complained of a decrease in the capacity for work (the group of healthy - 20\%). 60\% of patients in the I group and up to $80 \%$ of the patients in the II group, and $20 \%$ in the healthy group, complained 
Table 2. Results of the survey on the scale of Epfort of patients with $B A(M \pm m)$

\begin{tabular}{|c|c|c|c|c|c|}
\hline \multirow{3}{*}{ Indexes } & \multirow{2}{*}{\multicolumn{2}{|c|}{$\begin{array}{c}\begin{array}{c}\text { I group } \\
(\mathrm{n}=10)\end{array} \\
\text { Patients with mild persistent BA }\end{array}$}} & & oup & \multirow{3}{*}{$\begin{array}{l}\text { Healthy group } \\
\qquad(n=10)\end{array}$} \\
\hline & & & \multicolumn{2}{|c|}{ Patients with moderate BA } & \\
\hline & exacerbation & remission & exacerbation & remission & \\
\hline $\begin{array}{l}\text { Scale of drowsiness } \\
\text { of Epforta, points }\end{array}$ & $4,8 \pm 8,5^{\circ}$ & $3,9 \pm 9,2$ & $5,2 \pm 3,2^{4}$ & $4,7 \pm 3,2$ & $2,1 \pm 8,4$ \\
\hline
\end{tabular}

Notes: $1 .{ }^{*}$ - a significant difference in the indicator between the indicators in patients in the period of exacerbation and remission $(p<0,1)$; $2 .-$ a significant difference in the indicator compared with the healthy group $(p<0,1)$. Table 2 - Results of the survey on the scale of Epfort of patients with $B A(M \pm m)$

of periodic headache, ear cramps, dizziness, disorientation, and concentration of attention, memory and mood swings. On fluctuation of arterial pressure 2 patients from the group I and 4 patients from the group II and 2 from healthy group complained. All patients were polled on the scale of sleepiness of Epforth. According to the survey, $70 \%$ of patients in the group II, $40 \%$ of the first groupe and $20 \%$ of the healthy group complained of drowsiness of varying intensity - from mild to moderate.

In the phase of remission of the disease, $30 \%$ of patients in the I group and $60 \%$ in the II group remained complaints of periodic pain in the heart, a feeling of «heartbeat.» Of the 10 test group I, no one had an electrocardiogram of signs of left ventricular hypertrophy, sinus arrhythmia or signs of coronary heart disease. Of the 10 patients in the group II, 2 were signs of coronary heart disease, 1 - signs of left ventricular hypertrophy, 1 - sinus arrhythmia. $10 \%$ of the respondents of the first and $40 \%$ of the second group complained about the reduction of working capacity. For periodic headaches, ear cramps, dizziness, disorientation, and the severity of attention concentration, bad memory and mood swings, they complained to $10 \%$ of patients in the first group and up to $50 \%$ of patients on the second. None of the examined group I complained of fluctuations in blood pressure, and 3 patients in group II. According to the survey on the scale of Epforth, $10 \%$ of the first and $50 \%$ of patients in group II complained of drowsiness of varying intensity - from mild to moderate. The results obtained in more detail are presented in Table 2. In the healthy group the index of drowsiness was $(2.1 \pm 8.4)$ points, which significantly differed from the indicators of the groups, both in the phase of exacerbation and in the remission phase.

All patients throughout the observation period performed daily self-monitoring, in which they noticed: night asthma (the number of waking during the night due to respiratory symptoms) - in balls, morning stiffness in the chest (in balls), daytime symptoms (in balls), cough during the day (in balls), the average score of shortness of breath (in balls). Thus, all of the above symptoms were a total (total) asthma score (in balls). Also, patients noted selfmonitoring diaries in the number of inhaled SABA a day (salbutamol).

Estimation of the obtained indicators of the clinical course of BA was assessed separately for each group separately, depending on the degree of severity of the course of the disease and the variant of the basic treatment of the disease.

In the period of exacerbation, in all the patients under examination, the first group experienced shortness of breath under physical activity, attacks of stomach up to 1-2 times a day using inhalations

SABA, on average up to 2-3 times a day, moderate cough with spontaneous withdrawal, predominantly mucous membrane during the day, sometimes occuring morning chest tightness and nighttime symptoms 1-2 times a week. In $60 \%$ of the patients examined at the beginning of treatment, mucus sputum was present on average $(5.1 \pm$ 2.3) $\mathrm{ml}$ per day.

The systolic blood pressure in the group was on average $(135,2 \pm 7,5) \mathrm{mmHg}$, diastolic $-(81,5 \pm 7,5) \mathrm{mmHg}$, pulse $-(85 \pm 9,2) /$ min. The intensity of the indicator «cough» was on average $(1.9 \pm 4.2)$ points. The indicator of «shortness of breath» was on average $(1.8 \pm 5.4)$ points, the rate of «night awakening due to symptoms of BA» was on average $(0.8 \pm 7.1)$ points, «morning stiffness» $-(0.9 \pm$ $6.1)$ points, «Daily symptoms of the disease» - (0.8 \pm 8.2$)$ points. Total asthma score in the group was $(4.3 \pm 7.2)$ points. The need for SABA was $(2.8 \pm 6.1)$ times a day. More detailed information is presented in table 3 .

Table 3. Clinical manifestations of BA in the I group of patients according to the diary of self-observation in a week, during the period of exacerbation and remission $(M \pm m)$

\begin{tabular}{|l|c|c|}
\hline \multirow{2}{*}{\multicolumn{1}{|c|}{ Indexes }} & \multicolumn{2}{|c|}{ Prior to the study } \\
\cline { 2 - 3 } & \multicolumn{2}{c|}{$\begin{array}{c}\text { I group of patients (light } \\
\text { persistent course) (n=10) }\end{array}$} \\
\cline { 2 - 3 } & exacerbation & remission \\
\hline Night awakening & $0,8 \pm 7,1$ & $0,1 \pm 7,1^{*}$ \\
\hline Morning stiffness & $0,9 \pm 6,1$ & $0,1 \pm 6,1^{*}$ \\
\hline Daily symptoms & $0,8 \pm 8,2$ & $0,5 \pm 8,2^{*}$ \\
\hline Cough & $1,9 \pm 4,2$ & $0,9 \pm 4,2^{*}$ \\
\hline Dyspnea & $1,8 \pm 5,4$ & $0,8 \pm 5,4^{*}$ \\
\hline Common asthma account & $4,3 \pm 7,2$ & $2,4 \pm 7,2^{*}$ \\
\hline $\begin{array}{l}\text { Amount of application of } \\
\text { SABA }\end{array}$ & $2,8 \pm 6,1$ & $0,8 \pm 6,1^{*}$ \\
\hline
\end{tabular}

Note. * - clinically significant difference of the index in the I group of patients in the period of exacerbation and remission $(p<0,1)$. 
In the remission period, in all the subjects of the first group there was a slight shortness of breath with significant physical activity, attacks of stomach up to 2-3 times per week using SABA inhalation on average up to 3-4 times a week, a slight cough with sputum excretion predominantly mucous membrane during the day, sometimes occurring morning chest tightness and nightly symptoms 1-2 times a week. In $10 \%$ of the subjects, mucus sputum remained on average $(3.1 \pm 4.3) \mathrm{ml} /$ day.

Systolic blood pressure was on average $(115.2 \pm 7.5)$ $\mathrm{mmHg}$, diastolic $-(69,5 \pm 7,5) \mathrm{mmHg}$, pulse $-(65 \pm$ $9,2)$ / $\min$. The intensity of the indicator «cough» was on average $(0.9 \pm 4.2)$ points. The indicator of «shortness of breath» was on average $(0,8 \pm 5,4)$ points, the indicator «for nightly awakening due to the symptoms of BA» was on average $(0,1 \pm 7,1)$ points, «morning stiffness» was $(0,1 \pm 6,1)$ points, «day-to-day symptoms of the disease» - amounted to $(0,5 \pm 8,2)$ points. Total asthma score in the group was $(2.4 \pm 7.2)$ points. The need for SABA was $(0.8 \pm 6.1)$ times a day.

Before the beginning of the study in patients of the II group, there was an exacerbation of the disease, severity of asthma according to the classification of severity in them corresponded to 2-3 degrees (constant presence of prolonged daytime symptoms, exacerbation on average each 3 to 4 months, frequent nocturnal symptoms, partial limitation of physical activity due to $\mathrm{BA}, \mathrm{FEV}_{1}$ or POST from $60 \%$ to $80 \%$ of due, daily fluctuations of the OST or $\mathrm{FEV}_{1}>15 \%$, an increase in the frequency of use of SABA of no more than 8 inhalations per day, oral courses of oral corticosteroids (CS) are not more than 1-2 times a year. Systolic blood pressure was on average (145.2 \pm 6.5$)$ $\mathrm{mmHg}$, diastolic $-(82,5 \pm 5,5) \mathrm{mmHg}$, pulse $-(68 \pm$ $6,2) /$ min. 16 patients $(53.3 \%)$ had anamnesis of arterial pressure changes with debut of its increase, but officially the diagnosis of hypertonic disease as a concomitant had only 8 surveyed $(26.7 \%)$. Indicators were separately analyzed in a group of 17 patients in the baseline BA combination of long acting $\beta_{2}$-agonist (LABA) and ICS (group IIa) and separately in 13 patients receiving regular ICS monotherapy and SABA salbutamol (IIb group). The «cough» rate in the IIa group was on average $(2.6 \pm 7.8)$ points, in the IIb group $-(2.4 \pm 8.1)$ points. The total amount of sputum was in the IIa group on average to $(15.2 \pm 8.9) \mathrm{ml} /$ day, mucous in nature, in the group IIb - (13,2 $\pm 9,2)$ $\mathrm{ml} /$ day. The score for «dyspnea» was $(2.9 \pm 8.6)$ points in group IIa, in the IIb group - $(2.8 \pm 9.1)$ points, the indicator «night awakening due to symptoms of BA» was on average $(2.9 \pm 7,1)$ points in the IIa group, and $(3,0 \pm$ $7,9)$ in IIb, «morning stiffness» - $(2,2 \pm 8,1)$ points in the IIa group, and $(2,3 \pm 9,9) 1)$ in the IIb group. «Daytime symptoms of the disease»- was $(3.1 \pm 9.2)$ points in the group IIa and $(3.0 \pm 9.4)$ points in the IIb group. The total asthma score in the IIa group was $(13.7 \pm 9.2)$ points, in the IIb group $-(13.5 \pm 9.4)$ points. The need for use of SABA was $(3.1 \pm 5.1)$ times a day in the group IIa and $(3.8 \pm 6.1)$ in the group IIb. More detailed information is presented in Table 4.

In the remission phase, in patients with IIa the «cough» rate was moderate and averaged $(1,6 \pm 7,8)$ points, in the group IIb $-(0,58 \pm 8,6)$ points. The total amount of sputum was in the IIa group on average to $(6.9 \pm 8.9) \mathrm{ml}$ per day, mucous in nature, in the group $\mathrm{IIb}-(6.5 \pm 9.1) \mathrm{ml}$ per day. The indicator of «shortness of breath» was $(2.1 \pm 8.6)$ points in group IIa, in group IIb $-(1.4 \pm 8.6)$ points. All patients complained of nightly awakening due to the symptoms of BA: the index in the IIa group was on average (1.8 \pm $7.1)$ points, in the group IIb $-(1.6 \pm 8.1)$. The «morning stiffness» index in the IIa group was $(1.9 \pm 8.1)$ points, in the IIb group - $(1.6 \pm 9.1)$. The indicator «daily symptoms of the disease», on average, was $(2.5 \pm 9.2)$ points in group IIa and $(2.3 \pm 9.4)$ points in the IIb group. The total asthma score in the IIa group was $(9.9 \pm 9.2)$ points, in the IIb group $-(7.5 \pm 9.4)$ points. The need for SABA

Table 4. Clinical manifestations of BA in the II groups of patients according to the diary of selfobservation in a week, during the period of exacerbation and remission $(\mathrm{M} \pm \mathrm{m})$

\begin{tabular}{|c|c|c|c|c|}
\hline \multirow{4}{*}{ Indexes } & \multicolumn{4}{|c|}{ Prior to the study } \\
\hline & \multicolumn{4}{|c|}{ II group of patients (the moderate degree of severity) } \\
\hline & \multicolumn{2}{|c|}{ exacerbation } & \multicolumn{2}{|c|}{ remission } \\
\hline & group IIa $(n=17)$ & group IIb $(n=13)$ & group IIa $(n=17)$ & group IIb $(n=13)$ \\
\hline Night awakening & $2,9 \pm 7,1$ & $3,0 \pm 7,9$ & $1,8 \pm 7,1^{*}$ & $1,6 \pm 8,1^{*}$ \\
\hline Morning stiffness & $2,2 \pm 8,1$ & $2,3 \pm 9,1$ & $1,9 \pm 8,1^{*}$ & $1,6 \pm 9,1^{*}$ \\
\hline Daily symptoms & $3,1 \pm 9,2$ & $3,0 \pm 9,4$ & $2,5 \pm 9,2^{*}$ & $2,3 \pm 9,4^{*}$ \\
\hline Cough & $2,6 \pm 7,8$ & $2,4 \pm 8,1$ & $1,6 \pm 7,8^{*}$ & $0,58 \pm 8,6^{* \#}$ \\
\hline Dyspnea & $2,9 \pm 8,6$ & $2,8 \pm 9,1$ & $2,1 \pm 8,6$ & $1,4 \pm 8,6^{\text {*\# }}$ \\
\hline Total asthma account & $13,7 \pm 9,2$ & $13,5 \pm 9,4$ & $9,9 \pm 9,2^{*}$ & $7,5 \pm 9,4^{\text {*\# }}$ \\
\hline $\begin{array}{l}\text { Amount of application of } \\
\text { SABA }\end{array}$ & $3,1 \pm 5,1$ & $3,8 \pm 6,1$ & $2,8 \pm 5,1$ & $2,9 \pm 6,1^{*}$ \\
\hline
\end{tabular}

Notes: $1{ }^{*}$ - clinically significant difference of the indicator in the group of patients in the period of exacerbation and remission $(p<0,1)$; 2 .\# - is a clinically significant difference between the groups of patients $(p<0,1)$. 
Table 5. Clinical manifestations of asthma in the 1st and 2 nd group of patients according to the self-observation weekly diary, periods of exacerbation and remission $(M \pm m)$

\begin{tabular}{|c|c|c|c|c|c|c|}
\hline \multirow{3}{*}{ Indexes } & \multicolumn{6}{|c|}{ Patients with BA } \\
\hline & \multicolumn{3}{|c|}{ exacerbation } & \multicolumn{3}{|c|}{ remission } \\
\hline & $\begin{array}{l}\text { I group } \\
(n=10)\end{array}$ & $\begin{array}{l}\text { Ila group } \\
(n=17)\end{array}$ & $\begin{array}{l}\text { Ilb group } \\
(n=13)\end{array}$ & $\begin{array}{l}\text { I group } \\
(n=10)\end{array}$ & $\begin{array}{l}\text { Ila group } \\
(n=17)\end{array}$ & $\begin{array}{l}\text { Ilb group } \\
(n=13)\end{array}$ \\
\hline Night awakening & $0,8 \pm 7,1$ & $2,9 \pm 7,1$ & $3,0 \pm 7,9$ & $0,1 \pm 7,1^{*}$ & $1,8 \pm 7,1$ & $1,6 \pm 8,1$ \\
\hline Morning stiffness & $0,9 \pm 6,1$ & $2,2 \pm 8,1$ & $2,3 \pm 9,1$ & $0,1 \pm 6,1^{*}$ & $1,9 \pm 8,1$ & $1,6 \pm 9,1$ \\
\hline Daily symptoms & $0,8 \pm 8,2$ & $3,1 \pm 9,2$ & $3,0 \pm 9,4$ & $0,5 \pm 8,2^{*}$ & $2,5 \pm 9,2$ & $2,3 \pm 9,4$ \\
\hline Cough & $1,9 \pm 4,2$ & $2,6 \pm 7,8$ & $2,4 \pm 8,1$ & $0,9 \pm 4,2$ & $1,6 \pm 7,8$ & $0,58 \pm 8,6^{\#}$ \\
\hline Dyspnea & $1,8 \pm 5,4$ & $2,9 \pm 8,6$ & $2,8 \pm 9,1$ & $0,8 \pm 5,4^{*}$ & $2,1 \pm 8,6$ & $1,4 \pm 8,6^{\#}$ \\
\hline Common asthma account & $4,3 \pm 7,2$ & $13,7 \pm 9,2$ & $13,5 \pm 9,4$ & $2,4 \pm 7,2^{*}$ & $9,9 \pm 9,2$ & $7,5 \pm 9,4^{\#}$ \\
\hline $\begin{array}{l}\text { Amount of application of } \\
\text { SABA }\end{array}$ & $2,8 \pm 6,1$ & $3,1 \pm 5,1$ & $3,8 \pm 6,1$ & $0,8 \pm 6,1^{*}$ & $2,8 \pm 5,1$ & $2,9 \pm 6,1$ \\
\hline
\end{tabular}

Notes: $1 .{ }^{*}$ - a clinically significant difference in the parameters in the I group of patients in the period of exacerbation and remission $(p<0,1) ; 2$. \# - a clinically significant difference between Ila and II in the groups of patients in the period of exacerbation and remission $(p<0,1)$.

was in the IIa group $(2,8 \pm 5,1)$ times a day and in the IIb group $(2,9 \pm 6,1)$ times a day. Systolic blood pressure was on average $(132,2 \pm 6,5) \mathrm{mmHg}$, diastolic - (72,5 $\pm 5,5)$ $\mathrm{mmHg}$, pulse $-(72 \pm 6,2) /$ minute. More detailed information is presented in Table 5.

\section{Conclusions}

Consequently, as a result of the study, data from general clinical trials and questionnaires of patients with BA with varying degrees of disease severity and a variant of the received treatment in the remission phase and exacerbation were compared. Since an assessment was made between two groups of different degrees of severity, the significant difference in clinical and functional parameters of its course was maintained between the groups, both in the remission period and in the period of exacerbation.

It is established that the more severe the disease, the greater the percentage of patients with complaints, one of the causes of which is a violation of the functional state of the cardiorespiratory system. If the disease goes into the phase of exacerbation, then there is an increase in the dysfunction of the interconnected systems of the lung-heart, which leads to the deepening of existing or emerging new clinical manifestations of disorders in its functional state. This is confirmed by an increase in the percentage of patients with complaints of periodic pain in the heart, a feeling of «palpitations», decreased performance, periodic headache, ear cramps, dizziness, disorientation and the severity of attention concentration, bad memory and mood swings. It has been established that in the phase of exacerbation of the disease $60 \%$ of patients with a light persistent course and $80 \%$ of patients with the course of the disease of moderate severity complain of periodic pain in the heart and a feeling of «heartbeat» (the group of healthy ones - 20\%), in the remission phase, respectively, $30 \%$ and $60 \%$ of respondents $65 \%$ of patients in group I and $71 \%$ of patients with II group in the phase of exacerbation of asthma have complaints about decrease in capacity for work, then in remission phase $-55 \%$ and $60 \%$ respectively (the healthy group - 20\%). In the phase of exacerbation of BA, $60 \%$ of patients in the group I and $80 \%$ of the group II complain of periodic headaches, ear cramps, dizziness, disorientation, and the severity of attention concentration, bad memory and mood swings, in the remission phase of $40 \%$ and $60 \%$ respectively (the healthy group $-20 \%$ ). Complaints of drowsiness of different intensity in the phase of exacerbation were $49 \%$ of patients in group I and $96 \%$ of group II, in the remission phase $47 \%$ and $90 \%$ respectively (the healthy group $-20 \%$ ). 
Список літератури

1. Punjabi N.M., Newman A., Young T., et al. Sleep disordered breathing and cardiovascular disease: an outcome-based definition of hypopneas. Am J Respir Crit Care Med. 2008. Vol. 177. № 10. P. 1150-1155. DOI: 10.1513/pats.200709-155MG

2. Punjabi N.M., Beamer B.A. Alterations in glucose disposal in sleepdisordered breathing. Am J Respir Crit Care Med. 2009. Vol. 179. P. 235-240. DOI: 10.1152/japplphysiol.00695.2005 3. Rahangdale S., Yeh S.Y., Novack V., et al. The influence of intermittent hypoxemia on platelet activation in obese patients with obstructive sleep apnoea. J Clin Sleep Med. 2011. Vol. 7. № 2. P. $172-178$.

4. Фещенко Ю.І. Бронхіальна астма, хронічне обструктивне захворювання легень: перспективна глобальна стратегія ведення, новітні методи діагностики, сучасні підходи до терапії. Астма та алергія. 2015. № 4. С. 38-42.

5. Фещенко Ю.И., Яшина Л.А. Синдром обструктивного апноэ-гипопноэ сна - проблема ббщетерапевтическая. Здоров'я України. 2009. № 3. С. 48.

6. Global strategy for asthma management and prevention. National Institutes of Health National Heart \& Lung and Blood Institute. 2015. 132 p.

7. Фещенко Ю.И., Яшина Л.А. Бронхиальная астма. Doctor. 2004. № 2. С. 46-49.

8. Наказ МОЗ України №128 від 19.03.2007 р. «Про затвердження клінічних протоколів

надання медичної допомоги за спеціальністю «Пульмонологія». Київ : Велес, 2007. 148 с.

9. Бабич П.Н., Чубенко А.В., Лапач С.Н. Применение современный статистических методов в практике клинических исследований. Сообщение третье. Отношение шансов : понятие, 10. Лапач С.Н., Чубенко А.В., Бабич П.Н. Статистические методы в медико-биологиче10. Лапач С.Н., Чубенко А.В., Бабич П.Н. Статистические методы в меди

11. Punjabi N.M., Newman A, Young T., et al. Sleep disordered breathing and cardiovascular 11. Punjabi N.M., Newman A, Young T., et al. Sleep disordered breathing and cardiovascular disease: an outcome-based definition of hypopneas. Am
References

1. Punjabi NM, Newman A, Young T, et al. Sleep disordered breathing and cardiovascular disease: an outcome-based definition of hypopneas. Am J Respir Crit Care Med. 2008;177(10):1150-

1155. DOl: $10.1513 /$ pats.200709-155MG
2. Punjabi NM, Beamer BA. Alterations in glucose disposal in sleepdisordered breathing Am J Respir Crit Care Med. 2009;179:235-240. DOI: 10.1152/japplphysiol.00695.2005

3. Rahangdale S, Yeh SY, Novack V, et al. The influence of intermittent hypoxemia on platelet activation in obese patients with obstructive sleep apnoea. J Clin Sleep Med. 2011;7(2):172-178. 4. Feshchenko Yul. Bronchialna asthma, chronichne obstruktivne zachvoriuvannya legen globalna strategiya vedenya, novitni method diagnostiki, suchasni pidchodu do terapii. Asthma Allergia. 2015;4:38-42.

5. Feshchenko Yul, Yashina LA. Syndrom obsrtuktivnogo apnoe-hypopnoe sna - problema scheterapevticheskaya. Zdorovie Ukraine. 2009;3:48.

6. Global Strategy for Asthma Management and Prevention. National Institutes of Health National Heart \& Lung and Blood Institute. 2015. 132 p.

7. Feshchenko Yu I, Yashina LA. Bronchialna asthma. Doctor. 2004;2:46-49.

8. Nakaz MOZ Ukraine №128 vid 19.03.2007 «Pro zatverdjennya klinichnyich protokoliv nadanya medichnoi dopomogi za specialnistiy «Pulmonologya”. Kyiv: Veles, 2007. 148 p.

9. Babich PN, Chubenko AV, Lapach SN. Primenenye sovremennyich statisticheskich metodov $\checkmark$ praktike klinicheskich issledivanii. Soobschenie tretie. Otnoshenie shansov: ponyatie, vychisleie, interpritachya. Ukrainian medical chasopis. 2005;2(46):113-119.

10. Lapach SN, Chubenko AV, Babich PN. Statisticheskie methody v medico-biologycheskich issledovanyach sispolsovanyem Excel. Kiev: Morion, 2001. $320 \mathrm{p}$.

1. Punjabi NM, Newman A, Young T, et al. Sleep disordered breathing and cardiovascular dis(2008:177(10):11501155. DOI: $10.1164 / \mathrm{rccm} .200712-18840 \mathrm{C}$

\title{
ОЦЕНКА ДНЕВНОЙ АКТИВНОСТИ БОЛЬНЫХ БРОНХИАЛЬНОЙ АСТМОЙ В ЗАВИСИМОСТИ ОТ КЛИНИЧЕСКОГО ВАРИАНТА ТЕЧЕНИЯ ЗАБОЛЕВАНИЯ
}

\author{
А.А. Канарский
}

Резюме

Основной целью проведенной работы было оценить дневной образ жизни больных бронхиальной астмой (БА) в зависимости от контролируемости течения заболевания.

\section{Материалы и методы}

Исследования проводились на базе ГУ «Национальный институт фтизиатрии и пульмонологии им. Ф.Г. Яновского НАМН Украины». В результате проведенной работы было обследовано 40 больных БА (жители Киева и Киевской области) последовательно в фазе обострения и ремиссии в возрасте от 28 до 68 лет (средний возраст $(41,2 \pm 6,0)$ года), из них 17 мужчин и 23 женщины. При установлении диагноза БА учитывался анамнез, клинические симптомы, показатели функции внешнего дыхания, обратимость обструкции в пробе с бронхолитиком. В начале наблюдения всем больным, которым это было необходимо, проведена коррекция базового лечения заболевания соответственно тяжести заболевания. Тяжелой сопутствующей патологии не наблюдалось ни у одного из обследованных. В качестве контроля были обследованы 10 здоровых добровольцев, не имевших тяжелой клинически значимой патологии.

Результаты и выводы. В ходе исследования сравнивали данные общеклинических исследований и анкетирования больных БА с различной степенью тяжести заболевания и вариантом полученного базового лечения в фазе ремиссии и обострения. Поскольку проводилась оценка двух групп, различных по степени тяжести, то достоверная разница в клинико-функциональных показателях течения заболевания сохранялась между группами как в период ремиссии, так и обострения.

Установлено, что чем тяжелее течение заболевания, тем больший процент больных имеет жалобы, одной из причин возникновения которых является нарушение в функциональном состоянии кардиореспираторной системы. Если заболевание переходит в фазу обострения, то происходит усиление дисфункционирования взаимосвязанных систем легкие-сердце, что приводит к усугублению уже существующих или возникновению новых клинических проявлений нарушений в ее функциональном состоянии. Это подтверждается ростом процента больных с жалобами на периодические боли в сердце, ощущение «сердцебиения», снижение работоспособности, периодическую головную боль, шум в ушах, головокружение, рассеянность и тяжесть концентрации внимания, плохую память и колебания настроения. Установлено, что в фазе обострения заболевания 60\% больных с легким персистирующим течением и $80 \%$ больных с течением заболевания средней степени тяжести жалуются на периодические боли в сердце и ощущение «сердцебиения» (группа здоровых - 20\%), в фазе ремиссии - соответственно $30 \%$ и $60 \%$ опрошенных. $65 \%$ больных I группы и $71 \%$ больных II группы в фазе обострения БА имеют жалобы на снижение работоспособности, в фазе ремиссии - 55\% и $60 \%$ соответственно (группа здоровых - 20\%). В фазе обострения БА 60\% больных I группы и 80\% II группы жалуются на периодическую головную боль, шум в ушах, головокружение, рассеянность и тяжесть концентрации внимания, плохую память и колебания настроения, в фазе ремиссии $-40 \%$ и $60 \%$ соответственно (группа здоровых - 20\%). Жалобы на сонливость различной интенсивности в фазе обострения имели 49\% больных I группы и 96\% II группы, в фазе ремиссии - 47\% и 90\% соответственно (группа здоровых - $20 \%$ ).

Ключевые слова: бронхиальная астма, шкала Эпворта, сонливость.

Научно-практический журнал «Астма и аллергия», 2018, № 4 А.А. Канарский, младший научный сотрудник отделения пульмонологии ГУ «Национальный институт фтизиатрии и пульмонологии им. Ф.Г. Яновского НАМН Украины», ул. Н. Амосова, 10, г. Киев, УКРАИНА, 03038; тел.: +38(044) 275-30-21; e-mail: kanarskyialeksandr@gmail.com 


\section{ОЦІНКА ДЕННОЇ АКТИВНОСТІ ХВОРИХ НА БРОНХІАЛЬНУ АСТМУ В ЗАЛЕЖНОСТІ ВІД КЛІНІЧНОГО ВАРІАНТУ ПЕРЕБІГУ ЗАХВОРЮВАННЯ}

О.А. Канарський

\section{Резюме}

Основною метою проведеної роботи було оцінити денний спосіб життя хворих на бронхіальну астму (БА) в залежності від контрольованості перебігу захворювання.

Матеріали та методи. Дослідження проводилися на базі ДУ «Національний інститут фтизіатрії і пульмонології ім. Ф.Г. Яновського НАМН України». В результаті проведеної роботи було обстежено 40 хворих на БА (жителі Києва і Київської області) послідовно в фазі загострення і ремісії, віком від 28 до 68 років (середній вік $(41,2 \pm 6,0)$ року), з них 17 чоловіків і 23 жінки. Під час встановлення діагнозу БА враховувався анамнез, клінічні симптоми, показники функції зовнішнього дихання, оборотність обструкції в пробі з бронхолитиком. На початку спостереження всім хворим, яким це було необхідно, проведена корекція базового лікування захворювання відповідно до тяжкості захворювання. Тяжкої супутньої патології не спостерігалося в жодного з обстежених. Для контролю були обстежені 10 здорових добровольців, які не мали тяжкої клінічно значущої патології.

Результати та висновки. В результаті проведення дослідження порівнювали дані загальноклінічних досліджень та анкетування хворих на БА з різним ступенем тяжкості захворювання і варіантом отриманого базового лікування у фазі ремісії та загострення. Оскільки проводилася оцінка двох груп різних за ступенем тяжкості, то достовірна різниця клініко-функціональних показників його перебігу зберігалася між групами, як в період ремісії, так і під час загострення.

Встановлено, що тяжче перебіг захворювання, то більший відсоток хворих має скарги, однією 3 причин виникнення яких є порушення у функціональному стані кардіореспіраторної системи. Якщо захворювання переходить у фазу загострення, то відбувається посилення дисфункціонування взаємопов'язаних систем легені-серце, що призводить до поглиблення вже існуючих або виникнення нових клінічних проявів порушень їі функціонального стану. Це підтверджується зростанням відсотка хворих зі скаргами на періодичні болі в серці, відчуття «серцебиття», зниження працездатності, періодичний головний біль, шум у вухах, запаморочення, неуважність і тяжкість концентрації уваги, погану пам'ять і коливання настрою. Встановлено, що в фазі загострення захворювання 60\% хворих з легким персистуючим перебігом і 80\% хворих з перебігом захворювання середнього ступеня тяжкості скаржаться на періодичні болі в серці і відчуття «серцебиття» (група здорових - 20\%), в фазі ремісії - відповідно 30\% і 60\% опитаних. 65\% хворих I групи і 71\% хворих II групи в фазі загострення БА мають скарги на зниження працездатності, в фазі ремісії - 55\% і 60\% відповідно (група здорових - 20\%). У фазі загострення БА 60\% хворих I групи і $80 \%$ II групи скаржаться на періодичний головний біль, шум у вухах, запаморочення, неуважність і труднощі в концентрації уваги, погану пам'ять і коливання настрою, в фазі ремісії - 40\% і 60\% відповідно (група здорових - 20\%). Скарги на сонливість різної інтенсивності в фазі загострення мали 49\% хворих І групи і 96\% ІІ групи, у фазі ремісії - 47\% і 90\% відповідно (група здорових - 20\%).

Ключові слова: бронхіальна астма, шкала Епворт, сонливість.

Науково-практичний журнал «Астма та алергія», 2018, № 4 О.А. Канарський, молодший науковий співробітник відділення пульмонології ДУ «Національний інститут фтизіатрії і пульмонології ім. Ф.Г. Яновського НАМН Українш», вул. М. Амосова, 10, м. Київ, Україна, 03038; тел.: +30 (044) 275-30-21; e-mail: kanarskyialeksandr@gmail.com 